\title{
Wearable Textile Patch Antenna for Medical Applications
}

\author{
K. S. Chakradhar, Inumula Veeraraghava Rao, DT. Durga Prasad, P.Raju, V. Malleswara Rao
}

\begin{abstract}
In recent years of electronics industrialization, antennas are more popular components; wearable antennas play an important role due to their properties such as wireless communication and miniaturization. The design of wearable antennas have distinction in the area of antenna design and development, in this paper a thorough study had been carried out wearable antennas blended with textile, which has significant dielectric constant. This work describes the design a textile antenna, namely, a rectangular microstrip patch antenna and then rectangular with $U$-slot antenna with slits. After designing two kinds of antennas, a comparison will be made between their results. Conductive textile, a copper-plated polyester fabric, will be used for fabricating antenna radiators and grounds. An insulating denim fabric with dielectric constant 1.7 with a thickness of 0.7 is used for preparing the substrates. The proposed antenna is designed and all the results will calculated using Ansoft HFSS Software. After evaluating the results of a rectangular microstrip antenna and $U$-slot Antenna on textile substrate, the rectangular patch resonate at $2.5 \mathrm{GHz}$ with the return loss of $-16.86 \mathrm{~dB}$ and the $U$-slot Antenna resonated at $2.2 \mathrm{GHz}$ with return loss of $-41.68 \mathrm{~dB}$ and $3.9 \mathrm{GHz}$ return loss of $-16.16 \mathrm{~dB}$.
\end{abstract}

Keywords : wearable, textile antenna, wireless communication, Medical applications Microstrip, Antenna, microwave, HFSS

\section{INTRODUCTION}

Wearable antennas have become more popular in the recent research. Affluent mechanism of body centric communication is prevalent in the society promoting vast usage of wearable antennae. Wearable antennas are easily installable, less weight, cheap and maintenance free and are used universally. Many occupational segments of communication in real-time systems, such as health care, medical, time-critical systems, mission-critical systems need them. Besides, they are also used in in-house closed systems such as monitoring personalities, progression of behavior etc,. Several candidate antenna types are suitable to build a wearable antenna. Preferably, PIFAs, micro strips and planar monopoles, microstrip antenna out-perform amongst these categories, pre-fetch more compatibility for design and development of on-body wearable communication.

Patch antennas are particularlyfeasible for both on-body and off-body communication dueto the low profile they utilize

Revised Manuscript Received on December 13, 2019.

*Correspondence Author

K. S. Chakradhar,* Assoc. Professor, ECE Dept. Sree Vidyaniketan chakradharec@gmail.com

Inumula Veeraraghava Rao, Professor. Dept of ECE, GITAM Institute of Technology GITAM University, Visakhapatnam, A.P.,India

T. Durga Prasad, Professor. Dept of ECE, GITAM Institute of Technology GITAM University, Visakhapatnam, A.P.,India

Rama Raju. N. V. S, Professor. Dept of ECE, GITAM Institute of Technology GITAM University, Visakhapatnam, A.P.,India

Dr. V. Malleswara Rao, Professor. Dept of ECE, GITAM Institute of Technology GITAM University, Visakhapatnam, A.P.,India Engg. College (A), Kakinada, Tirupathi, A.P., India:

[1]. Antennas consisting ofplanar sheets are ideal to be fabricated using conventionalmanufacturing processes of textile industry. Furthermore,the ground plane of such antenna effectively shields theantenna from the body tissues [2]. This minimizes bothdetuning and reduction of antenna efficiency. However,circularly polarized patch antennas tend to be sensitive tobending effects [3 - 4].Rectangular patch geometry isadopted for further examination of circularly polarizedtextile antenna. This geometry is shown to be relativelyrobust against bending effects [5].

Wireless communication technology is ushering in the research and playing a very important role in developing new stereotypes and prototype of products and in the revise of Wireless Body Area Networks (WBANs). The expanse of WBAN is the living body and it connects the different electronic devices inside with on the human body. The urge of WBAN applications pays dire attention today in the fields of medical, national defense and wearable computing. The constitutional elements of WBANs run on varied frequencies especially on Medical Implant Communication Systems (MICS: $400 \mathrm{MHz}$ ) band, the Industrial Scientifics Medical (ISM: $2.4 \mathrm{GHz}$ and $5.9 \mathrm{GHz}$ ) band and the Ultra-Wideband (UWB: 3-10 GHz) [6]. According to IEEE 802.15.6, WBAN applications that insist on military, ubiquitous health care, sports, entertainment and many others, are classified into two areas, such as middle and non-medical. [8].

\section{DESIGN AND GEOMETRY OF TEXTILEANTENNA}

The general considerations for the design of wearable communication systems are compact transmitter, minimized power consumption, optimized signal transmission over the human body, which are the rudimentary criteria pose the design challenge. Miniaturization, invisibility, omni-directional radiation pattern are the technical considerations for transmission, which should always take into account the antenna orientation, position of the receiver, adjustment and adjustment to compensate for body conditions. Recent studies on development of wearable antennas satisfying the requirements follow in this section.

A denim substrates with relative permittivity of $\varepsilon_{\mathrm{r}}=1.7$ and thickness $(\mathrm{h})=3.5 \mathrm{~mm}$, losses tangent $(\tan \delta)=0.01$ is considered for design and demonstration of proposed antenna in the experiments. The location and fitting of the antenna by respect to its width, length of patch, ground plane and reflectors are mathematically analyzed and ascertained its usage [1].

Published By:

Blue Eyes Intelligence Engineering 


$$
W=\frac{(\text { velocity of light) }}{2 f \sqrt{\frac{\epsilon_{r}+1}{2}}}
$$

Effective Dielectric constant $\varepsilon_{\text {reff }}$ is known by

$$
\begin{gathered}
\text { for } \frac{w}{h} \geq 1 \\
\epsilon_{\text {reff }}=\text { 0.5. }\left(\epsilon_{r}+1\right)+0.5 .\left(\epsilon_{r}-1\right)\left[1+12 h \cdot w^{-1}\right]^{-0.5}
\end{gathered}
$$

The dimensions of the patch are extended to account the fringing effects. The extension is given by,

$$
\Delta L=0.412 h \frac{\left(\epsilon_{\text {reff }}+0.3\right)\left(w \cdot h^{-1}+0.264\right)}{\left(\epsilon_{\text {reff }}-0.258\right)\left(w \cdot h^{-1}+0.8\right)}
$$

Since the length has been extended on each side of the patch, the effective length is given by,

$$
L_{e f f}=\frac{(0.5) .(\text { velocity of light })}{f \sqrt{\epsilon_{\text {reff }}}}
$$

Patch Length $=(\text { Patch Length })_{\text {effective }}-2($ Change in Length $)$ The ground plane dimensions are calculated by using the following formulae:

ground plane - length

$$
\mathrm{L}_{\mathrm{g}}=6 \mathrm{~h}+\mathrm{L}
$$

ground plane - width

$$
\mathrm{W}_{\mathrm{g}}=6 \mathrm{~h}+\mathrm{W}
$$

\section{SIMULATION OF TEXTILEANTENNA GEOMETRY}

A rectangular patch antenna is an ISM band variant, with 2.4 $\mathrm{GHz}$ frequency is license free, adopted in wide range of applications. A jeans textile material, which has a dielectric constant 1.7, with height substrate of $3.5 \mathrm{~mm}$ is a suitable form for designing wearable patch antenna. Since its substrate height (thickness) is $3.5 \mathrm{~mm}$ and less than $3.5 \mathrm{~mm}$ does not give $\mathrm{S}_{11}$ at desired level.

The performance of the antenna is improved by employing the U-slot inside the patch and which slits at the edge of the patch. Generally, textiles have low dielectric constant, reduced surface wave losses and increased impedance bandwidths, while in antenna. A self-adhesive copper tape is used to fabricate the prototype of wearable antenna and with scalar network analyzer in the experiments.

\section{A. Structure of ReferenceAntenna}
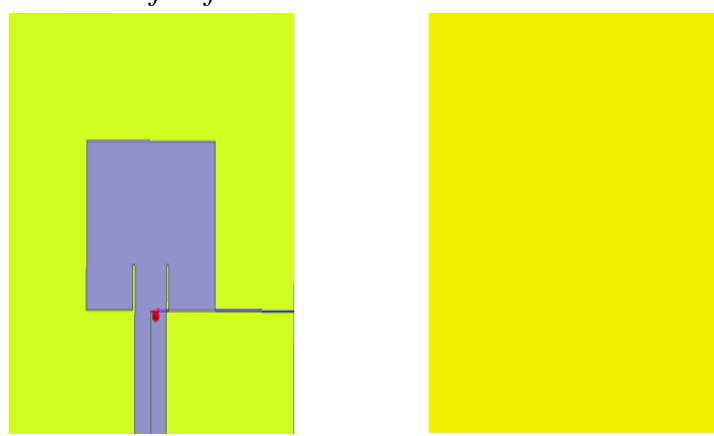

Fig.1. A View of Wearable Textile Patch Antenna
B. Structure of U-Slotted Antenna With Slits

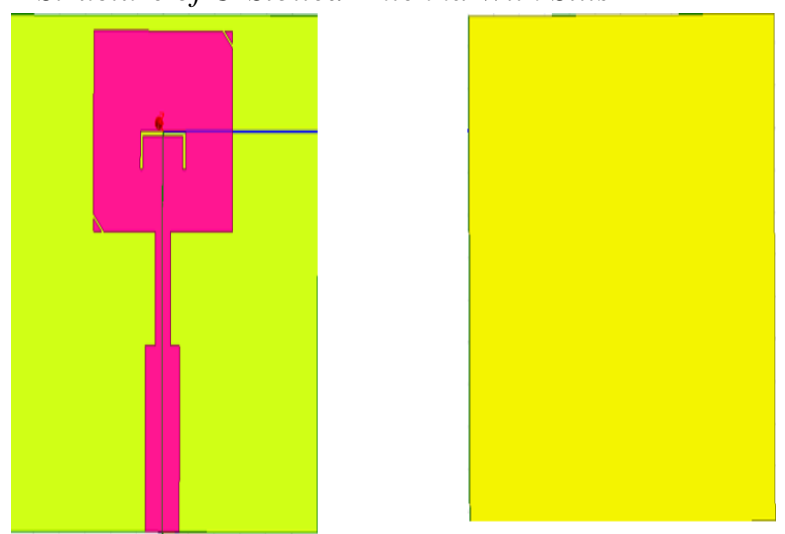

Fig.2. A View of Wearable Textile Patch Antenna with U-Slot

Table-I:Dimensions of Reference Rectangular Textile Patch Antenna and with U-slot

\begin{tabular}{|l|l|l|}
\hline \multicolumn{1}{|c|}{$\begin{array}{c}\text { Design } \\
\text { Parameter }\end{array}$} & \multicolumn{1}{|c|}{$\begin{array}{c}\text { Calculated } \\
\text { Value for } \\
\text { Rectangular } \\
\text { patch Antenna }\end{array}$} & $\begin{array}{c}\text { Calculated } \\
\text { Value for } \\
\text { Rectangular } \\
\text { MPA with U } \\
\text { slot }\end{array}$ \\
\hline $\begin{array}{l}\text { Antenna } \\
\text { Frequency }\end{array}$ & $2.4 \mathrm{GHz}$ & $2.4 \mathrm{GHz}$ \\
\hline \multicolumn{1}{|c|}{$\varepsilon_{\mathrm{r}}$} & 1.7 & 1.7 \\
\hline Antenna height & $3.5 \mathrm{~mm}$ & $3.5 \mathrm{~mm}$ \\
\hline Antenna width & $53.6974 \mathrm{~mm}$ & $53.6974 \mathrm{~mm}$ \\
\hline Antenna length & $46.6 \mathrm{~mm}$ & $46.6 \mathrm{~mm}$ \\
\hline $\begin{array}{l}\text { Microstrip Line } \\
\text { width }\end{array}$ & $13.1197 \mathrm{~mm}$ & $13.1197 \mathrm{~mm}$ \\
\hline $\begin{array}{l}\text { Substrate } \\
\text { dimensions }\end{array}$ & $\begin{array}{l}120 \mathrm{~mm} \mathrm{X} \mathrm{120} \\
\mathrm{mm}\end{array}$ & $\begin{array}{l}120 \mathrm{~mm} \mathrm{X} \\
120 \mathrm{~mm}\end{array}$ \\
\hline Length of feed line & $12.45 \mathrm{~mm}$ & $43.307 \mathrm{~mm}$ \\
\hline
\end{tabular}

\section{RESULTS}

\section{A. Results of the Reference Antenna}

Figure 3 and 4 shows the resultant $S_{11}$ and VSWR of the reference patch. As it can practical that the antenna radiates at $2.5 \mathrm{GHz}$ with $-16.86 \mathrm{~dB}$ of $\mathrm{S}_{11}$. In parallel, the VSWR is obtained at 1.36 .

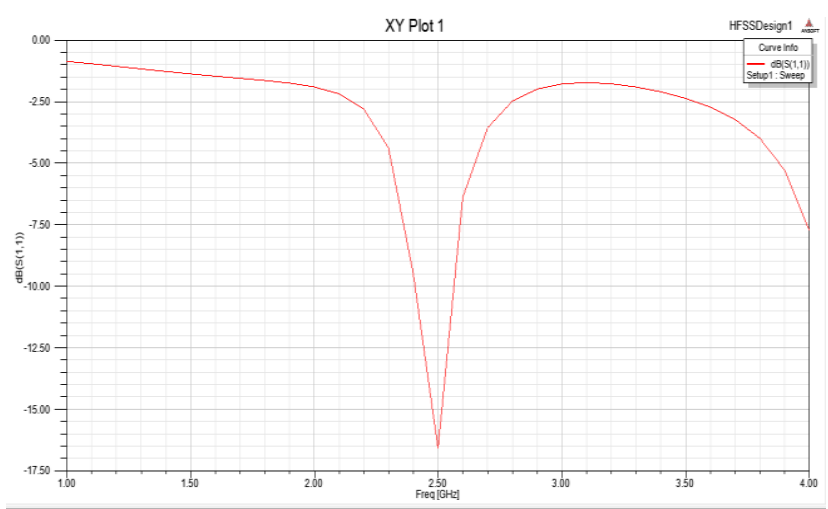

Fig .3. Return loss of the reference Textile Antenna in HFSS 


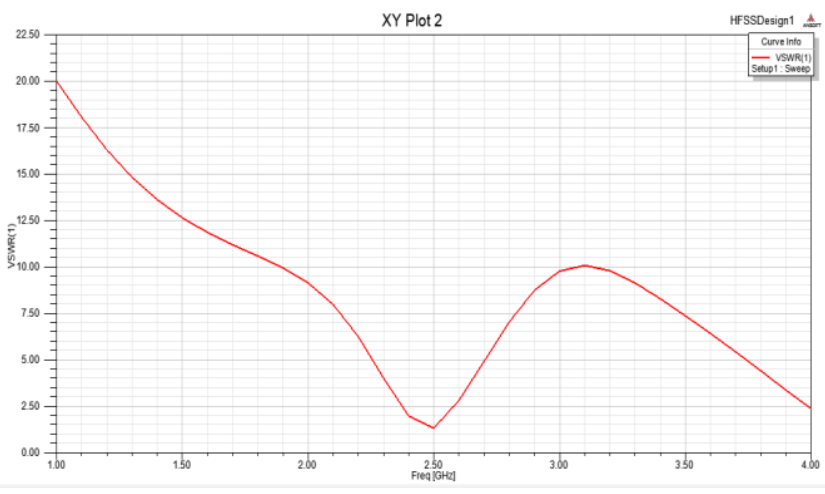

Fig .4. VSWR of the reference Textile Antenna in HFSS
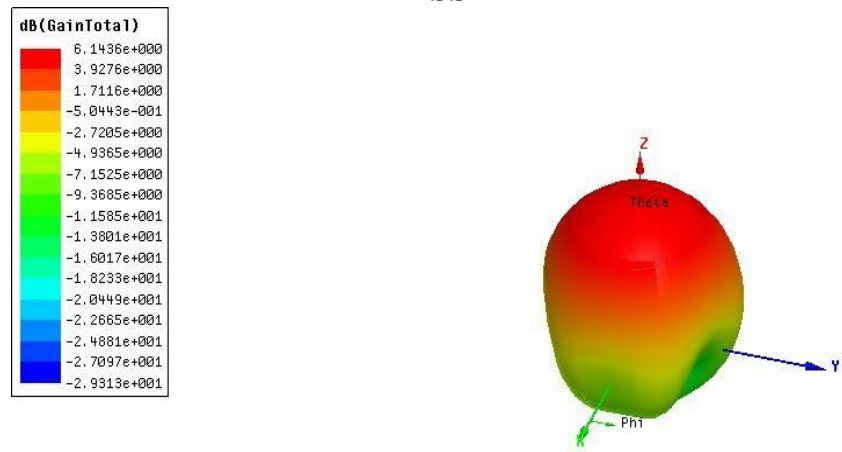

Fig. 5.Gain of the reference Textile Antenna

The gain of the antenna is obtained as $6.14 \mathrm{~dB}$ from the fig.5.
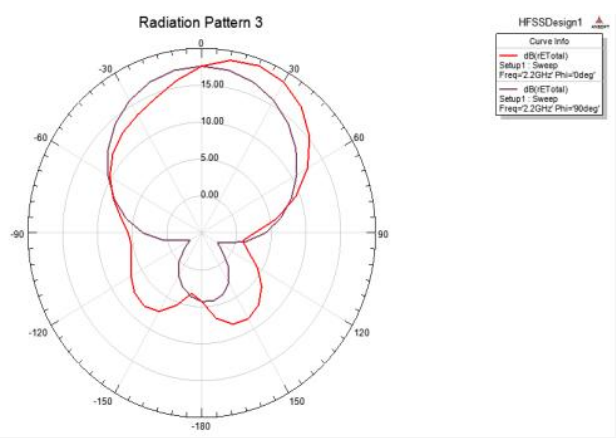

Fig.6 Radiation Pattern of the reference TextileAntenna

B. Results of the U-Slotted Antenna withslits

Figure 7 and 8 show the simulated Return loss $\left(S_{11}\right)$ and VSWR of the textile patch antenna with U-Slot. As it can observe that Textile antenna radiates at two bands $2.2 \mathrm{GHz}$ and $3.9 \mathrm{GHz}$ with $-41.68 \mathrm{~dB}$ and $-16.16 \mathrm{dBreturn}$ loss respectively. On the Other hand, VSWR is 1 at $2.2 \mathrm{GHZ}$ and 1.4 at $3.9 \mathrm{GHZ}$.

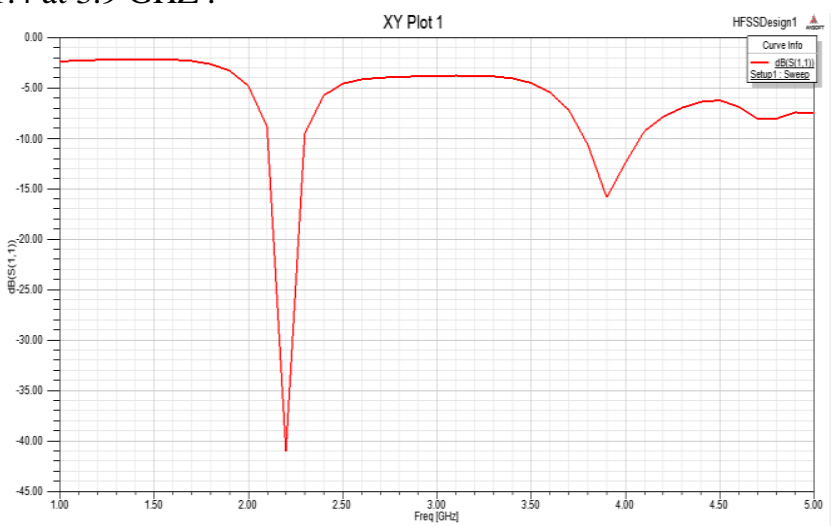

Fig .7Return loss of the Wearable Textile Antenna The fig. 6 shows the radiation pattern of the MPA

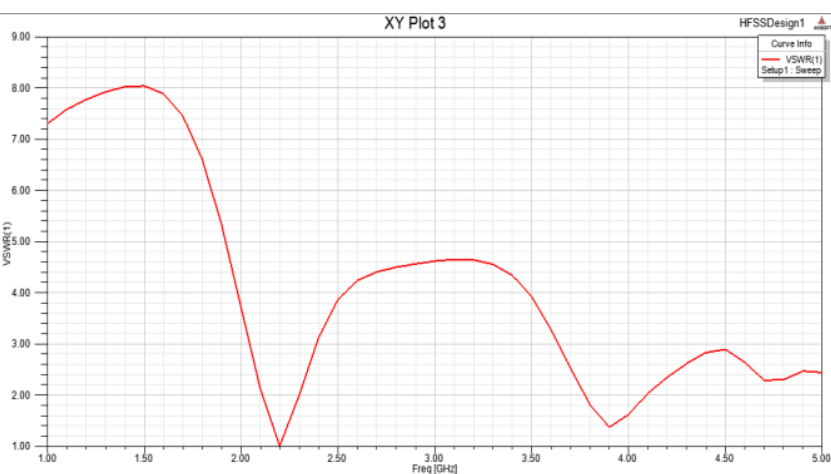

Fig .8.VSWR of the Wearable Textile Antenna

From the fig. 8 the VSWR is obtained as 1 at $2.2 \mathrm{GHz}$ and 1.4 at $3.9 \mathrm{GHz}$
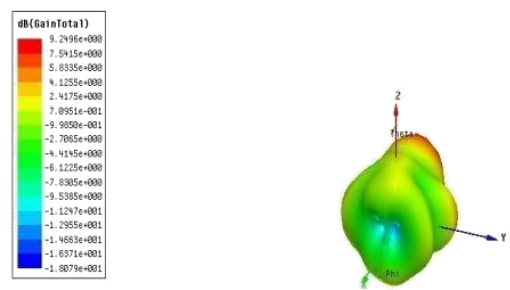

Fig .9 Gain of the Wearable Textile Antenna

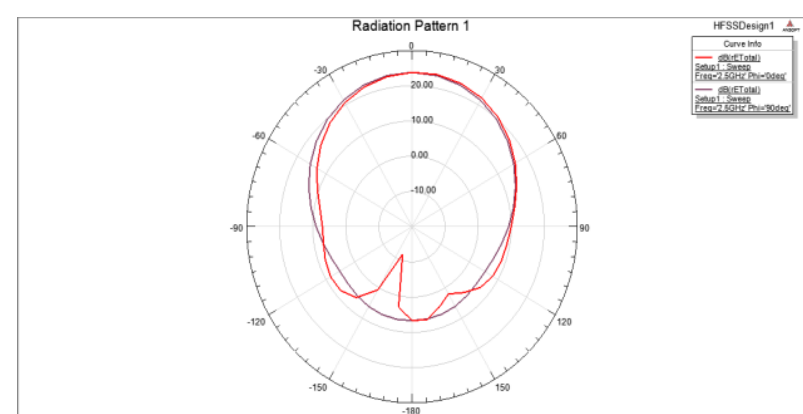

Fig .10Radiation Pattern of the Wearable Textile Antenna

Table-II: Comparison of rectangular patch and U-slot

\begin{tabular}{|c|c|c|c|c|}
\cline { 2 - 5 } \multicolumn{1}{c|}{} & $\begin{array}{c}\text { Resonating } \\
\text { Frequency }\end{array}$ & $\begin{array}{c}\text { Return Loss } \\
\boldsymbol{S}_{I I}\end{array}$ & VSWR & Gain \\
\hline $\begin{array}{c}\text { Rectangular } \\
\text { Microstrip } \\
\text { patch Antenna }\end{array}$ & $2.5 \mathrm{GHz}$ & $-16.86 \mathrm{~dB}$ & 1.36 & 6.14 \\
\hline $\begin{array}{c}\text { Patch with } \\
\text { U-slot }\end{array}$ & $2.4 \mathrm{GHz}$ & $-41.68 \mathrm{~dB}$ & 1 & \multirow{2}{*}{9.24} \\
\cline { 2 - 5 } & $3.9 \mathrm{GHz}$ & $-16.16 \mathrm{~dB}$ & 1.4 & \\
\hline
\end{tabular}

\section{CONCLUSION}

The candidate antenna for wearable applications is a micro strip antenna. In general all textile material are assumed to have has low $\varepsilon_{\mathrm{r}}$ as 1 to 2 , a micro strip antenna can be a built-in into a fabric substrate material with a bandwidth of $200 \mathrm{MHz}$. Especially textiles has a distinct characteristic of reduced surface wave losses which gives improvised antenna bandwidth. In the proposed experimentation, textile antenna structures are tested and obtained results on their performances. The return loss of $-41.68 \mathrm{~dB}$ at $2.2 \mathrm{GHz}$ and VSWR is 1 for U-slot are noted according to simulated results. 


\section{REFERENCES}

1. C. A. Balanis, 'AntennaTheory', JohnWiley and Sons, $3^{\text {rd }}$ edition, 2005

2. H Singh, "Electromagnetics and Antenna", Katson publications, Delhi, 2nd edition.

3. Kuo-Shen Chi, Chi-Shen Wu, 'Designs of textile antenna arrays for smart clothing applications', june 2018

4. Sudhir Shrestha, Mangilal Agarwal,"Microstrip Antennas for Direct Human Skin Placement for Biomedical Applications"july 2010 .

5. Chan Hwang See and Khalid G Samarah "A Printed Widebands MIMO Antenna for Mobile and Portable Communication Device”, APACE 2003. Asia-Pacific Conference on Applied Electromagnetics, pp: 38 :41, 2003.

6. K. Kwon and J. Chi. "Antenna for Wireless Body Area Network,"7th European Conferences on Antennas and Propagation (EuCAP),2013. pp.375-379.

7. Lim. E.G. Z. Wan, M. Leach, ZhouR, K. L. Man and N. Zhang,'Compact Size of Textile Wearable Antenna', Proceedings of The International MultiConference of Engineers and Computer Scientists 2014, IMECS 2014, 12-14 March, 2014, Hong Kong, pp:870:873.

8. S. Movassagh, M. Abolhasan, J. Lipman, "Wireless Body Area Network: A Survey", IEEE Communication Survey \& Tutorials:2013. p.1-20

9. Sweety Purohits and Falguni Rava, "Wearable-Textiles Patch Antennas using Jean as Substrated at 2.45GHZ" International Journal of Engineering and Technology ,ISSN : 2278:0181 , Vol:3,Issue -5, May:2014

10.Abdullahi Ayegba, Wysenyuy Desmond, "Design of a $4.5 \mathrm{GHZ}$ Rectangular Microstrip Patch Antenna”, International Journal of Trends in Research and Development-Volume 4(3), ISSN : 2394:9333

\section{AUTHORS PROFILE}

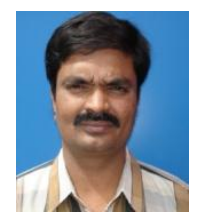

K.S.Chakradhar, completed M.E. in the stream of Electronics \& Control Engineering from Sathyabama Deemed University, Chennai in the year of 2005 and pursuing Ph.D at GITAM university, Visakhapatnam. Currently, working as Associate Professor in Sree Vidyanikethan Engineering College (A), Tirupathi, India. Micro strip Patch antennas and VLSI are the interest areas.

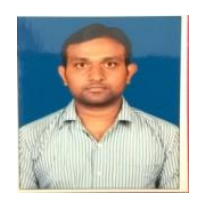

I Veera raghava Rao Pursuing $\mathrm{PhD}$ in GITAM,Visakhapatnam having keen interest in Wireless Communication .

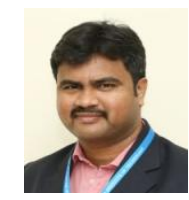

T.Durga Prasad, working as Assistant Professor in GITAM .Areas of Interest are Antennas, Microwave engineering.

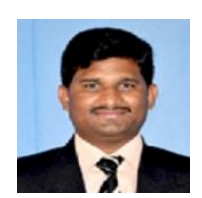

Raju.P, working as Assistant Professor in GITAM .Areas of Interest are Digital image processing,Signal processing,Biomedical signal processing

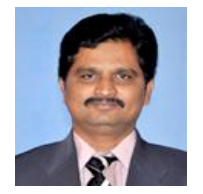

Dr. V. Malleswara Rao, working as Professor in GITAM (Deemed to be University) from past 30 years. He has been published more than 75 articles in national and international Journals. 